\title{
KRITIK ATAS PUISI-PUISI KARYA AHMAD NURULLAH DAN NANING PRANOTO $^{1}$
}

\author{
Kasno Atmo Sukarto \\ Universitas Nasional Jakarta \\ 0817767736 \\ kasnoas@yahoo.com
}

Received July 17, 2019, Revised August 3, 2019, Approved September 17, 2019

\begin{abstract}
ABSTRAK
Berbicara tentang kritik sastra, secara umum, selain untuk menghakimi karya sastra, juga memiliki fungsi untuk mengkaji dan menafsirkan nilai karya sastra baik novel, cerpen, maupun puisi. Tujuan penulisan ini adalah untuk mendeskripsikan dan menafsirkan nilai karya sastra yakni Puisi-Puisi Langit Biru yang mencerminkan adanya kepedulian terhadap lingkungan hidup karena pencemaran udara. Teori yang diterapkan untuk mendeskripsikan adalah kritik pandangan "Tiga M Kritik Sastra Sawo Manila: Menghibur, Mendidik, dan Mencerdaskan. Metode penulisan ini adalah deskriptif kualitatif yaitu menafsirkan nilai-nilai puisi, menghibur, mendidik, dan mencerdaskan dalam Puisi-Puisi Langit Biru. Hasilnya menunjukkan bahwa dalam karya sastra khususnya dalam puisi karya Ahmad Nurullah dan Naning Pranoto terdapat makna yang mengangkat pentingnya lingkungan hidup bagi kehidupan manusia atas pencemaran udara dan lingkungan yang kurang sehat.
\end{abstract}

Kata Kunci: Kritik Sastra, Puisi, Menghibur, Mendidik, Mencerdaskan

\begin{abstract}
Generally, literary criticism function for both judging literary work and interpreting novel, short story, and poetry. This article aims at describing and interpreting 'Puisi-Puisi langit Biru' which is reflecting the concern for the environment due to air pollution. This article used the three M Sawo Manila: Menghibur, Mendidik, and Mencerdaskan (Entertaining, Educating, and Developing Mind) Theory. The method of the study employs descriptive qualitative, which is interpreting the values of poetry, those are Menghibur, Mendidik, and Mencerdaskan (Entertaining, Educating, and Developing Mind). The result shows that in literary works, poems written by Ahmad Nurullah and Naning Pranoto, there are meanings that raise the importance of the environment for human life for air pollution and an unhealthy environment.
\end{abstract}

Key Words: Literary Criticism, Poetry, Entertaining, Educating, Developing Mind

\footnotetext{
${ }^{1}$ Makalah telah disajikan dalam rangka Konferensi Nasional Bahasa dan Sastra V yang diselenggarkan oleh Program Studi S-3 Pendidikan Bahasa Indonesia, Fakultas Keguruan dan Ilmu Pendidikan UNS bekerja sama dengan Asosiasi Dosen Bahasa dan Sastra Indonesia (ADOBSI) dan Perkumpulan Pengelola Jurnal Bahasa dan Sastra Indonesia serta Pengajarannya (PPJB-SIP) di Universitas Sebelas Maret Surakarta pada tanggal 19 Oktober 2019.
} 


\section{PENDAHULUAN}

\section{Latar Belakang}

Setakat ini berbicara tentang kritik sastra khususnya dalam dunia pengajaran memang tiada henti-hentinnya. Oleh karena itu, tidak mudah untuk memulai suatu perbincangan tentang kritik sastra — karena kita hampir selalu berada dalam keraguan dan perasaan yang kurang enak.Izad, http://www//qureta.com/post/apa-kabar-kritik-

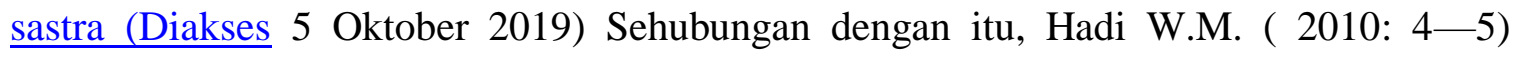
menyatakan bahawa teori tersembunyi pandangan hidup sistem nilai, dan gambaran dunia tertentu yang hendak dijakdikan acuan terhadap penilaian karya sastra.

Berdasarkan hal di atas, karya sastra misalnya puisi yang mengadung nilai nilai dan mencerminkan kehidupan manusia dan lingkungannya belum banyak dibicarakan oleh para pembaca khususnya kritikus sastra. Meskipun ada, kritik sastra yang berkaitan dengan lingkungan hidup belum banyak dibicarakan oleh pengamat sastra termasuk kritikus sastra. Misalnya Puisi-Puisi Langit Biru karya Ahmad Nurullah dan Naning Pranoto belum pernah dikaji dan diperbincangkan oleh khalayak yang membidangi masalah sastra.

Puisi-Puisi langit Biru ini secara keseluruhan menggambarkan dan mengandung nilai-nilai lingkungan hidup bagi kehidupan manusia. Hal semacam itu, jika diamati dan jika dianalisis secara mendalam, hasilnya akan dapat dinikmati oleh pembaca. Pembaca dapat mengerti dan memahami sekaligus dapat memetik hasilnya setelah membaca puisi yang dibacanya. Dengan membaca yang sarat dengan pelestarian lingkungan ini, pembaca dapat terhibur, dan mendapat Edukasi dan kecerdasan. Puisi yang sarat dengan imbauan mencintai lingkungan ini mempunyai makna yang mendalam khususnya ikhwal lingkungan hidup, misalnya bahaya asap kendaraan bermotor, pencemaran udara, dan pentingnya penghijauan terhadap lingkungan hidup bagi kehidupan manusia.

Untuk menilai dan menafsirkan puisi-puisi yang mencerminkan pentingnya lingkungan itu, penulis ingin menerapkan ancangan kritik sastra Sawo Manila yaitu Tiga M Kritik Sastra Sawo Manila: Menghibur, Mendidik, dan Mencerdaskan. Dalam

Menelaah Puisi-Puisi Langit Biru ini penulis hanya membatasi puisi-puisi karya Ahmad Nurullah dan Naning Pranoto. 


\section{Rumusan Masalah}

Berdasarkan latar belakang, rumusan masalah penulisan ini adalah sebagai berikut.

1. Bentuk Puisi seperti apa yang menyiratkan ikhwal lingkungan hidup?

2. Bagaimana pendekatan Tiga M Kritik Sastra Sawo Manila: Menghibur, Mendidik, dan mencerdaskan dapat diterapkan untuk mengkaji Puisi-Puisi Langit Biru?

\section{Tujuan Penulisan}

Berdasarkan rumusan masalah dalam penulisan ini, tujuan penulisan ini adalah seperti berikut.

1. Mendeskripsikan puisi-puisi karya Ahmad Nurullah dan Naning Pranoto.

2.Menelaah puisi-puisi karya Ahmad Nurullah dan Naning Pranoto.

\section{Tinjauan Pustaka}

\section{Ikhwal Kritik Sastra}

Pembaca setelah membaca karya sastra akan dapat menilai dan mengevaluasi atas karya sastra yang telah dibacanya itu, sehingga pembaca dapat menilai baik dari sisi bentuk maupun isi. Dengan kata lain, pembaca dapat menilai atas baik buruknya karya sastra yang dibacanya - dan tidak dapat menilai tanpa dilandasi adanya dasar agar dapat mengerti dan memahami ikhwal sastra dan karya sastra yang telah dibacanya tahap demi tahap, sehingga pembaca akan terarah bagaimana pembaca dapat mengerti, memahami, dan menilai karya sastra yang dibacanya.

Tentang Kritik Sastra: Sebuah Pendirian Lagi oleh Effendi telah menyiratkan adanya sanggahan-sanggahan atas tulisan Arief Budiman dan Gunawan Muhamad, yakni dalam pengertian yang benar bahwa kritik sasatra adalah ilmu — secara realitas pertemuan antara pribadi sang kritikus dan karya sastra sebagai ekspresi pribadi seorang manusia

lain. Effendi, 2016: 19). Effendi telah memberikan pernyataan bahwa sastra atas karya orang lain itu dapat dinilai sebagai suatu pengalaman estetika atas imajinasi pengarang berdasarkan realitas yang dialami pengarang.

Ikhwal kritik sastra juga dipaparkan oleh Hanum bahwa kritik adalah penilaian yang bersifat rasional dan objektif (Hanum, 2016: 24). Atas dasar pandangan Hanum itu 
telah membuktikan bahwa kritik sastra merupakan suatu tindakan atas karya sastra untuk mengerti, memahami, dan menilai secara objektif, baik itu karya sastra fiksi maupun nonfiksi. Mengerti tidaknya membaca karya sasrta tidak hanya cukup sekali membaca, tetapi karya sastra bisa dibaca sekali, dua kali, bahkan tiga kali agar dapat mengerti benar isi yang terkandung dalam karya sastra. Pembaca dapat memahami karya sastra yang telah dibacanya berarti pembaca dapat mengerti benar atau mengetahui benar isi karya sastra yang telah dibacanya. Dengan kata lain, pembaca dapat memahami isi karya sastra yang telah dibancanya itu termasuk karya sastra yang bernilai tinggi atau tidak bernilai tinggi "karya sastra fiksi dan nonfiksi". Menilai karya sastra berarti pembaca dapat menentukan nilai atau menghargai atas karya sastra yang telah dibacannya. Untuk itu, pembaca secara objektif dapat memberikan penghargaan atas karya sastra yang telah dibaca, misalnya puisi, cerpen, dan novel.

Atas dasar paparan di atas, dapat diberi benang merah penulisan ini adalah bagaimana Tiga M Kritik Sawo Manila dapat memberikan pandangan dan menunjukkan atau dapat mengungkap adanya nilai yang mendidik, menghibur, dan mencerdaskan.

\section{Sejarah Kritik Sastra Indonesia}

Kritik Sastra Indonesia diawali pada abad ke-19 yakni ketika pendekatan sastra diutamakan untuk memahami nilai-nilai karya sastra yang berkaitan dengan aspek-aspek kebudayaan dalam arti yang luas. Dalam arti luas misalnya menyangkut masalah kebudayaan, adat istiadat, kemasyarakatan, sosial, dan agama. Dengan demikian, kritik sastra dapat dikatakan kritik tanpa batas. Kritik tanpa batas artinya kritikus sastra dapat menilai, memuji, menikmati atas karya sastra yang telah dibacanya.

Kritik sastra Menurut Sastrowardoyo dalam "Sekilas Soal Sastra dan Budaya" (1982) yang dikutip (Hanum, 2016: 25--26) yang menyatakan bahwa kritik sastra

hendaknya adanya tahapan seperti berikut. (1) Kritik sastra sebagai kecaman atau pujian, (2) Kritik sastra sebagai perantara penikmat sastra dan karya sastra, (3) Kritik sastra sebagai penelitian ilmiah, dan (4) Kritik sastra sebagai kajian filsafat.

Pandanagan Sastrowardoyo tentang kritik sastra itu telah menunjukkan bahwa karya sastra secara umum mengandung unsur-unsur yang dapat dipuji atas nilai-nilai yang terkandung di dalamnya, misalnya nilai-nilai kebaikan atas tokoh yang ada dalam karya sastra itu. Unsur menikmati, pembaca dapat menikmati atas karya sastra yang 
menunjukkan adanya tuntunan dan tindakan tokoh yang secara positif dapat sebagai panutan. Kritik sastra sebagai penelitian ilmiah bahwa karya sastra misalnya pusisi, cerpen, dan novel dapat dipakai sebagai objek penelitian ilmiah. Kritik sastra sebagai kajian ilmiah bahwa karya sastra dapat dijadikan objek penelitian karya ilmiah karena di dalam karya sastra terkandung tentang falsafah kehidupan dan pandangan hidup manusia.

Atas dasar pandangan Sastrowardoyo itu dalam hal yang sama telah dikatakan oleh Pradopo. Teori Kritik dan Penerapannya dalam Sastra Indonesia Modern. http://ugmpress.ugm.ac.id/id/product/bud. (Diakses 5 Oktober 2019) menyatakan bahwa sastra Indonesia perlu adanya kritik demi pengembangan sastra Indonesia. Hal itu penting mengingat karya sastra selalu berkembang baik karya sastra melalui media cetak maupun media daring. Keseimbangan antara kritik dan karya sastra memang harus ada. Kritik sastra muncul karena ada karya sastra dan karya karya muncul dan berkembang karena adanya kriktik sastra.

Kritk sastra Indonesia mengemuka yang diawali adanya Tentang Kritik Sastra: Sebuah Diskusi Diskusi tentang kritik sastra ini diadakan di gedung Balai Budaya, Jakarta pada tanggal 31 Oktober 1968. Penggagas kegiatan diskusi kritik sastra ini adalah Arief Budiman dan Gunawan Muhamad dari Dewan Kesenian Jakarta, S. Effendi dari Direktorat Bahasa dan Kesusastraan (sekarang: Badan Pengembangan Bahasa dan Perbukuan ), dan J.U. Nasution dari Lembaga Kesusastraan, Fakultas Sastra, Universitas Indonesia (sekarang: Fakultas Ilmu Budaya). Kegiatannya adalah mengumumkan tanggapan-tanggapan atas kritik sastra melalui majalah dan surat kabar.

Oleh karena itu, bagi peneliti sastra perlu digalakan kegiatan penelitian sastra. Kemudian, hasil kegiatan pembicaraan tentang kritik sasatra itu dikumpullkan untuk diterbitkan agar dapat diketahui sampai seberapa jauh kegiatan kritik sastra (Budiman et al, 1978, v-vi).

\section{Kritik Sastra Rawamangun}

Munculnya Kritik Sastra Rawamangun ini diilhami adanya Pengajaran Kesusastraan Indonesia Modern di Fakultas Sastra (sekarang: Fakultas Ilmu Budaya) Universitas Indonesia (lihat Hutagalung, 1975: 15-20). Kritik Sastra Aliran Rawamangun ini dipelopori oleh 1) M. Saleh Saad, 2) Lukman Ali, 3) S. Effendi, dan 4) M.S. Hutagalung. Alir Rawamangun ini berdiri bersamaan dengan hancurnya Lekra 
Jurnal Pujangga Volume 5, Nomor 2, Desember 2019

ISSN P 2443-1478

ISSN E 2443-148

yaitu pada tahun 1966. Prinsip aliran ini adalah bahwa pusat penelitian sastra adalah karya sastra itu sendiri.

\section{Tiga M Kritik Sastra Sawo Manila}

Tiga M Kritik Sastra Sawo Manila merupakan nama kritik sastra yang lahir pada tahun 1987 di Fakultas Sastra (sekarang: Fakultas Bahasa dan Sastra) Universitas Nasional Jakarta. Aliran Kritik Sastra Sawo Manila ini lahir bertepatan dengan berdirinya Lembaga Penelitian Bahasa dan Sastra, Fakultas Sastra, Universitas Nasional. Aliran ini dipelopori oleh 1) Wahyu Wibowo, 2) Leonard Gultom, 3) Zulfa Hanum, dan 4) Hamdan Jassin. Konsep Kritik Sastra Tiga M in adalah Mendidik, Menghibur dan Mencerdaskan. Menghibur berarti bahwa bahwa karya sastra yang dibaca tidak terbatas pada nilai-nilai atau unsur-unsur vulgar. Mendidik berarti bahwa karya sastra baik puisi, cerpen maupun novel mempunyai unsur didik yang positif. Mencerdaskan pembaca, sekurang-kurangnya akan mendapat wawasan yang luas, pengetahuan tentang ikhwal kehidupan manusia. Dengan demikian, hasilnya akan dapat mencerdaskan pembaca sekaligus dapat mengembangkan akal budinya untuk selalu berpikir, bertindak, mengerti dan memahami arti kehidupan yang diperoleh setelah membaca karya sastra.

Atas dasar pemikiran Tiga $M$ itu, pembaca ketika membaca karya sastra memperoleh wawasan yang luas yakni dengan membaca karya sastra dapat menghibur ketika waktu senggang. Mendidik yang awalnya tidak tahu menjadi tahu. Mencerdaskan berarti mendapat wawasan yang luas tentang segi kehidupan manusia yang kesemuanya itu dapat diperoleh setelah membaca karya sastra.

\section{METODE PENELITIAN}

Di dalam penulisan ini, penulis menerapkan metode deskriptif kualitatif yakni penulis mendeskripsikan data-data karya sastra yang terpilih yang menyiratkan unsurunsur atau nilai-nilai karya sastra yang dapat menghibur, mendidik, dan mencerdaskan khususnya puisi-puisi yang mengandung usur-unsur pencemaran udara dan lingkungan hidup. Dalam menelaah puisi, penulis menerapkan "Tiga M Kritik Sastra Sawo Manila: Menghibur, Mendidik, dan Mencerdaskan”. Adapun teknik yang dilakukan dalam 
pengambilan data adalah teknik sampel yang terpilih yang berkaitan dengan unsur menghibur, mendidik, dan mencerdaskan. Objek penulisan ini adalah Puisi-Puisi Langit Biru Karya Ahmad Nurullah, Aric MP Tamba, Naning Pranoto, dan Sides Sudyarto. Untuk objek data. Sebagai sampl penulisan ini, penulis hanya mengambil sampel beberapa puisi karya Naning Pranoto dan Ahmad Nurullah. Hal itu dilakukan karena kajian ini merupakan penelitian awal.

\section{HASIL DAN PEMBAHSAN}

Kritik sastra Sawo Manila yang yang lazim disebut Tiga M Kritik Sastra Sawo Manila ini mempunyai konsep Mendidik, Menghibur dan Mencerdaskan. Konsep itu menawarkan suatu kajian sastra yakni jika kita kaitkan dengan dunia pengajaran sastra dapat mengisi dan saling memberikan. Dengan kata lain, Mengisi artinya kita setelah membaca karya sastra, kita akan dapat hiburan, dapat didikan, dan sekaligus mendapat kecerdasan (Kasno, 1997: 26).

Konsnep-konsep di atas dapat diterapkan misalnya untuk karya-karya berikut. Puisi-Puisi Langit Biru Karya Ahmad Nurullah, Arie MP Tamba, Sides Sudyarto D S, dan Naning Pranoto yang diterbitkan oleh penerbit Swisscontact dan Garda Budaya Indonesia, tanpa tahun. Kumpulan merupakan kumpulan puisi tentang lingkungan hidup. Puisi-puisinya mengandung makna tentang pendidikan lingkungan hidup, hiburan, dan sekaligus mengajak pembaca untuk berpikir bahwa atas kecerdasan untuk bertindak manusia dapat memelihara dan melestarikan lingkungan hidup dengan baik.

\section{ESOK, LANGIT LEBIH BIRU \\ Puisi Ahmad Nurullah}

"Kubayangkan: esok langit lebih biru

Seperti warna kelopak matamu."

Anak-anak itu berlari-lari

Bermain riang di bawah langit bersih

Di bawah gugusan awan berarak putih. 
$\mathrm{O}$, alangkah indahnya alam yang segar

Lingkungan yang nyaman.

Udara yang bersih

"Semoga langit lebih biru.

Seperti warna kelopak matamu

Esok, jauh saat setelah kau jadi ibu."

Ahmad Nurullah mengajak pembaca untuk sekadar mengisi waktu. Puisinya tersirat makna mengajak, mendidik pembaca untuk menyikapi betapa pentinganya lingkungan yang nyaman, udara besih di bawah arak-arak awan putih terhindar dari pencemaran udara. Untuk itu, harapan dan perlu pemikiran untuk melestarikan lingkungan agar lingkungan hidup tetap terjaga kebersihannya, udara tetap bersih, agar esok udara tetap terjaga kebersihannya.

\section{LANGIT PUN TERSENYUM PADA KITA \\ Puisi Ahmad Nurullah}

Tahukah: apa dampak pencemaran udara

bagi kesehatan hidup kita?

Jawabannya, sederet kengerian berbayang di depan mata:

Meracuni sistem pembentukan sel darah merah -

penyebab anemia

Mengganggu pertumbuhan sistem syaraf, terutama

perkembangan otak

Menekan tensi darah hingga menjadi tinggi -

mengganggu kerja jantung

Apa yang mesti kita lakukan

guna mengurangi pencemaran udara?

Kita tahu jawabannya. Misalnya:

Rawatlah mesin kendaraan kita — agar rendah polusi 
Pakailah bahan bakar gas - sebab lebih bersih dan

murah lagi!

Di dalam lingkungan bebas encemaran udara

Hidup kita lebih terjaga

Tubuh sehat

Langit seakan tak henti-hentinya tersenyum pada kita

Ahmad Nurullah tampaknya mengajak pembaca untuk pentingnya memahami pencemaran udara terhadap kesehatan kehidupan manusia. Pencemaran udara dapat meracuni sistem pembentukan sel-sel darah merah, dapat mengganggu pertumbuhan sistem saraf dan teutama gangguan kerja jantung. Selain itu, dengan membaca puisi pembaca akan mendapat hiburan ringan sekaligus mendapat pendidikan betapa pentinganya pendidikan tentang lingkungan bersih dari pencemaran udara. Kecerdasaan manusia dibutuhkan untuk memikirkan arti dan pentingnya lingkungan bersih dari pencemaran udara.

\section{ASAP ADALAH MONSTER}

Mamandang dari trotoar, berbagai jenis

kendaraan bermotor meraung - meradangng

menyemburkan monster-monster putih dan hitam

menyerbu udara

Ya, asap adalah monster, Ada yang warnanya hitam, ada yang putih. Ada juga yang tidak kelihatan.

Namun semua sama bahayanya bagi kesehatan

Bahkan bisa menyeret pada kematian

Tentu saja lewat udara cemar yang terhirup

lewat hidungmu.

Mengapa asap ada yang hitam, ada yang putih, dan yang tidak kelihatan? 
Asap hitam adalah karbon: terjadi karena bahan bakar solar tidak terbakar sempurna

Sedang asap dari kendaraan berbahan bakar bensin umumnya tidak terlihat oleh mata.

Namun, beberapa kendaraan berbahan bakar bensin dapat pula menyemburkan asap putih sebab oli mesin ikut terbakar

Asap adalah monster Malka itu mari kita hindari asap Usahakan hidup di udara segar: Bebas dari asap monster yang berbahaya dan mematikan

Ahmad Nurullah dalam puisi ini tampaknya menginformasikan kepada khalayak agar menghindari asap akibat kendaraan bermotor. Asap adalah monster yang dapat mengganggu pernapasan manusia. Puisi ini tersirat makna adanya imbauan agar menghindari asap-asap akibat kendaraan bermotor baik yang berbahan bakar solar maupun bensin. Jika asap dianggap monster dapat mencemarkan udara dan membahayakan, pembaca hendaknya dapat menyikapi betapa pentinganya kebersihan udara, lingkungan yang sehat dalam kehidupan manusia. Imbauan edukasi tentang lingkungan hidup tersirat dalam puisi ini agar pembaca dapat terhibur, teredukasi dalam pemahaman pentingnya lingkungan hidup bagi kehidupan manusia sutuhnya. .

\section{AKU INGIN MEMBASUH LANGIT}

Puisi Naning Pranoto

Ingin aku membasuh langit, Mama

Biar segar bersih parasnya

Ingin aku menyeka angkasa

Agar tetap cerah barcahaya

Agar setiap insan panjang usia 
Ingin aku menjaga bumi, Mama

Agar tiada lagi pencemar udara

Agar tiada lagi asap hitam bertuba

Aku rindu langit tetap biru

Sepanjang hidupku

Naning Pranoto tampaknya mengimbau, mengajak pembaca agar sadar betapa pentingnya arti kebersihan udara, kesegaran udara, kecerahan udara, terhindar dari pencemaran. Selain itu, udara tetap terjaga dari asap hitam akibat dari kepulan asap kenalpot kendaraan bermotor. Dalam konteks hiburan, dengan membaca puisi Naning Pranoto, pembaca mendapat hiburan ringan. Mencerdaskan, Naning mengajak pembaca untuk berpikir secara cerdas bagaimana pentingnya lingkungan hidup agar tetap terjaga dari udara yang kotor akibat dari asap-asap mesin bermotor.

\section{TAMAN-TAMAN TUMBUH DI KOTAKU}

\section{Puisi Naning Pranoto}

O, Papa, O Mama! O, Papi, O, Mami!

O, Ayahandaku, O, Ibundaku

Izinkan aku bermimpi

Mimi yang indah sekali

Di kotaku telah turun hujan

Bukan hujan air, tetapi hujan taman

Taman tumbuh di mana-mana di kotaku

Taman pepohonan, taman benungaan

Semua bertumbuh, semua bersemi

Semua berbuanga indah sebagai surge

Taman-tamanku, paru-paru kotaku

Kukecup selalu harum wangi tamanku.

Tampaknya Naning Pranoto dalam mimpinya melalui puisinya ini telah mengajak pembaca untuk menikmati taman pepohonan, taman bebungaan di kota. Setelah membaca 
puisi ini, setidaknya pembaca akan mendapat hiburan ringan. Selain itu, pembaca mendapat pendidikan betapa pentingnya arti taman kota dan pepohonan kota bagi masyaralat lingkungannya. Yang tidak kalah pentingnya lagi adalah puisi ini tersirat ikhwal kecerdasan berpikir positif untuk memasyarkatkan pentingngya lingkungan hidup yang bersih bagi kehidupan manusia.

\section{SIMPULAN}

Berdasarkan deskripsi dan pembahasan, konsep Tiga M Kritik Sastra Sawo Manila dapat diterapkan untuk mengkaji karya sastra. Contoh Puisi karya Ahmad Nurullah dan Naning Pranoto dapat dijadikan sebagai contoh yang dapat dikaji dengan menerapkan konsep Tiga M. Dengan membaca puisi kedua pengarang tersebut, pembaca mendapat manfaat makna yang tersirat yaitu dapat terhibur dengan membaca puisi karya Ahmad Nurullah dan Naning Pranoto. Teredukasi kesadaran akan arti dan pentingnya lingkungan hidup bagi kehidupan manusia. Kecerdasan, dengan membaca puisi, pembaca diajak untuk berpikir dan bertindak untuk menyikapi pentingnya lingkungan hidup dari bahaya asap dan pencemaran udara yang diawali dengan tindakan pribadi. 


\section{DAFTAR PUSTAKA}

Effendi, S. 2016. Studi, Kritik, dan Apresiasi Sastra. Tangerang: Pustaka Mandiri.

Hadi W.M., Abdul. 2010. "Sastra dan Matinya Ideologi”. Dalam Pusat: Majalah Sastra. Edisi 3.

Hanum, Zulfa. 2016. Kritik Sastra: Sebuah Penilaian terhadap Karya Sastra. Tangerang: Pustaka Mandiri.

Hutagalung, M.S. 1975. Kritik Atas Kritk. Jakarta: Yayasan Tulia.

Izad, Rohmatul. http://www//qureta.com/post/apa-kabar-kritik-sastr

(Diakes 5 Oktober 2019)

Pradopo, Rachmat Djoko. 2017 Teori Kritik dan Penerapannya dalam Sastra Indonesia Modern. Yogyakarta: UGM Press. http://ugmpress.ac.id/id/product/bud ( Diakses 5 Oktober 2019).

Kasno. 1997. Sastra Indonesia dalam Peningkatan Sumber Daya Manusia”. Dalam Suara Guru.1.

Sukarto, Kasno Atmo. 2018. "Kritik Sastra dan Implementasi Pengajaran”. Pujangga: Jurnal Bahasa dan Sastra. Volume 4. Nomor 1. Juni.

Wibowo, Wahyu. 1987. Tiga M. Lembaga Penelitian Bahasa dan Kesusastraan. Jakarta: Fakultas Sastra, Universitas Nasional. 